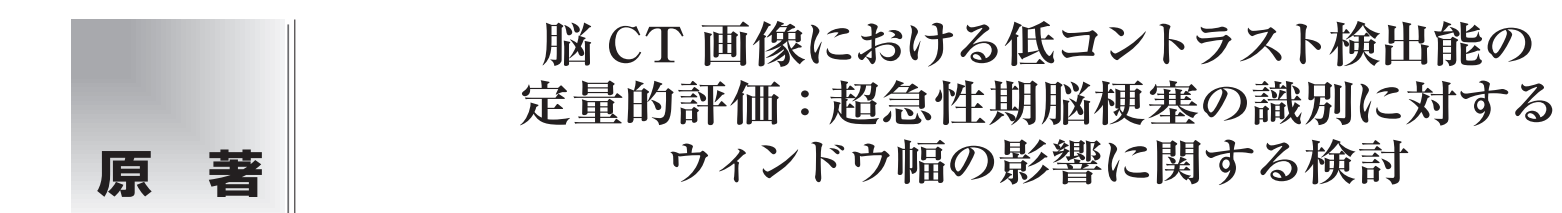

長島宏幸 ${ }^{1)} \cdot$ 岩崎隆史 ${ }^{2)} \cdot$ 須永眞一 ${ }^{3)}$ ・後閑隆之 之) $^{4}$ 藤井雅典 ${ }^{5)}$ 佐藤 慶 $^{(6)} \cdot$ 根岸 徹 $^{1)} \cdot$ 白石明久 $^{1)} \cdot$ 小倉敏裕 $^{1)} \cdot$ 土井邦雄 ${ }^{1)}$

2011 年 6 論文受付
月28
論文受理
Code Nos. 251 年 10 月 3 日2
522

緒

超急性期脳梗塞における computed tomography (CT) 検査は, これまで脳内出血や脳腫瘍などの除外 診断が主体であったが，マルチスライス CT 装置の 登場により，薄いスライス像を加算するスタックス

\author{
1 )群馬県立県民健康科学大学診療放射線学部 \\ 2) 慶友整形外科病院画像診断科 \\ 3)桐生厚生総合病院放射線科 \\ 4) 中央群馬脳神経外科病院放射線科 \\ 5) 老年病研究所附属病院画像診断部 \\ 6) 社会保険群馬中央総合病院放射線科
}

\title{
Quantitative Evaluation of Low Contrast Detectability in a Brain Computed Tomography: Investigation for the Effect of Window Width on Recognition of Hyperacute Ischemic Stroke
}

Hiroyuki Nagashima, ${ }^{1)}$ Takahumi Iwasaki, ${ }^{2)}$ Shinichi Sunaga, ${ }^{3)}$ Takayuki Gokan, ${ }^{4)}$ Masanori Fujii, ${ }^{5)}$ Kei Sato, ${ }^{6)}$ Toru Negishi, ${ }^{1)}$ Akihisa Shiraishi, ${ }^{1)}$ Toshihiro Ogura, ${ }^{1)}$ and Kunio Doi ${ }^{1)}$

1 ) Gunma Prefectural College of Health Sciences

2) Keiyu Orthopaedic Hospital

3) Kiryu Kosei General Hospital

4) Central Gunma Neurosurgical Hospital

5) Geriatrics Research Institute and Hospital

6) Gunma Chuo General Hospital

Received June 28,2011; Revision accepted October 3, 2011; Code Nos. 251, 522

\section{Summary}

In diagnostic brain computed tomography (CT) imaging of hyperacute ischemic stroke, the recognition of subtle lesions is difficult and may be missed. The aim of this study was to evaluate quantitatively the effect of the window width on low contrast detectability by using digital phantom images intended for detection of hyperacute ischemic stroke, and clinical CT images. We first derived the digital phantom images by subtracting the simulated signal data (intensity $=1-3$ hounsfield units (HU), diameter $=10-30 \mathrm{~mm}$ ) from the water phantom images at various mAs values. Observer studies were then performed under the various window widths at $20,40,60$, and $80 \mathrm{HU}$ by using the 30 digital phantom images and the 30 water phantom images. In addition, observer studies on brain CT images with 30 abnormal cases and 30 normal cases were performed under the window widths at 20 and $80 \mathrm{HU}$. Studies were also performed under the simultaneous display of the set of brain CT images on each window width. As a result of evaluation by receiver operating characteristic analysis, narrowing of the window width can improve the low contrast detectability in CT images with noticeable noise, and can decrease the variation in the interpretation skills between observers in clinical CT images. Moreover, the interpretation accuracy was improved by displaying simultaneously the clinical CT image set on window widths at 20 and $80 \mathrm{HU}$.

Key words: computed tomography (CT), hyperacute ischemic stroke, window width (WW), low contrast detectability, receiver operating characteristic (ROC) analysis

別刷資料請求先： $\bar{\top}$ 371-0052 前橋市上沖町 323-1

群馬県立県民健康科学大学 長島宏幸 宛 
になった。しかし，CT 画像上の早期虚血変化は，非 常に淡い低吸収域を呈するため, 視覚的に識別しに くく, 不適切な撮影条件下で撮影された場合には見 落とされることがあり, 観察者間で認識に差が生じる と報告されている ${ }^{1 \sim 3)}$. また, 各施設で撮影され, the European cooperative acute stroke study(ECASS)に登 録された 620 症例の脳 CT 画像において, 画像不良 な症例が $20 \%$ 存在したと報告されている4). したがっ て，施設ごとでの超急性期脳梗塞を対象とした CT 検 査における至適撮影パラメー夕の設定が必要である.

これまで，脳 CT 画像における低コントラスト検出 能の向上を目的とした, 線質に関わる管電圧や, 画像 ノイズに関わるスキャン方式, $\mathrm{X}$ 線出力, スライス 厚, および画像再構成関数などの撮影パラメータの 最適化に関する研究は, 数多く報告されている ${ }^{5 \sim 11)}$. また, middle cerebral artery embolism local fibrinolytic intervention trial Japan(MELT Japan)では, 脳 CT 検 査における撮影条件と画像表示条件の標準化を行 い，さらに，読影訓練プログラムを用意して，早期虚 血変化に対する検出能の向上を図っている ${ }^{12)}$. MELT Japanの報告の中で，画像表示条件であるウィンドウ 幅(window width; WW)の設定は, 80 hounsfield units (HU) 以下とすることが推奨されている. 一方, 臨床 画像における主観的評価により，WW を狭くして観察 することが有効であるという報告がされている13,14). また，Levらは，超急性期脳梗塞症例が含まれた 30 例の CT 画像の WW を $8 \mathrm{HU}$ に初期設定し, 神経放 射線科医 2 名が WW を 1 30 HU まで変化させなが ら観察した結果，WWを $80 \mathrm{HU}$ に設定した表示条件 に比べて，読影精度が向上したと報告している15)。し かし，この報告は，シングルスライス CT 装置で撮影 された画像を利用した結果であり，また，全症例に 対して同一の撮影条件で撮影されているため, WW の変化が画像ノイズの異なる CT 画像の信号検出能 に及ぼす影響についての検討はなされていない.さ らに，観察者実験に利用した症例数や観察者数が少 ないため, 統計的な信頼性に疑問が残る。これま で, 超急性期脳梗塞の CT 画像における表示条件の 最適化に関する研究報告は, Levらの報告以外に存 在せず，画像ノイズが変化した CT 画像における WW が及ぼす信号検出能の影響に関する基礎的な研 究報告はされていない.

われわれは，管電流時間積 (mAs 值)を変化させて 撮影した水ファントム画像を用いて, 超急性期脳梗 塞を対象とした低コントラスト検出能を評価するため のディジタルファントム画像を作成し, WW が低コン トラスト検出能に及ぼす影響についてシミュレーショ ン実験を行った。 また，マルチスライス CT 装置で撮
影された，超急性期脳梗塞症例が含まれる 60 例の CT画像を用いて, 10 名の観察者による receiver operating characteristic(ROC) 実験を施行し, WW の 違いにおける読影精度への影響について検討したの で報告する。

\section{1. 方 法}

1-1 ディジタルファントム画像を用いた実験

超急性期脳梗塞を対象とした CT 検査における撮 影パラメータの最適化に関する研究は，主に CT 值の 差が最小 $5 \mathrm{HU}$ の信号を用いた性能評価ファントムを 用いて検討されている7,11)。しかし，超急性期脳梗塞 を伴う脳実質部の CT 值は，含水量の $1 \%$ 変化にお いて $2.6 \mathrm{HU}$ 低下し ${ }^{1)}$ ，また，発症してから間もない 虚血領域における周辺組織との CT 值の差 (CT 值差) は，1〜3 HU 程度であると報告されている7)。した がって，超急性期脳梗塞をシミュレーションした低コ ントラスト検出能の評価を行う場合, 既存の性能評 価ファントムでは適応外となる。原ら ${ }^{16)}$ は, 周辺部と の CT 值差が $2 \mathrm{HU}$ となる固形ファントムを作成し, 低コントラスト分解能の評価を行っており，極めて有 用な研究であると考える。しかし，各施設で簡便に 利用できるものではなく，沉用性に関してそしいもの と推測する。本研究では, 既存の水ファントムを撮影 した CT 画像と画像処理技術を用いて作成した信号画 像からディジタルファントム画像を作成し, WW が低 コントラスト検出能に及ぼす影響について検討した。

\section{1-1-1 ディジタルファントム画像の作成}

本研究では, 4 data acquisition system(DAS)の マルチスライス CT 装置(Light Speed Plus: GE 横河 メディカルシステム社製)を使用した。まず，既存 の京都科学社製の性能評価ファントム (JIS Z4923 $200 \mathrm{~mm} \phi)$ を専用支持台に配置し，ファントム中心を CT ガントリ内中心に設定して画像ノイズ評価用のス キャン位置を撮影し，ノイズ画像を収集した。撮影 条件は，スキャンモード：コンベンショナル，管電 圧 : $120 \mathrm{kV}$, 再構成スライス厚 : $10 \mathrm{~mm}(2.5 \mathrm{~mm} \times 4$ DAS), 再構成関数: STANDARD, FOV : $200 \mathrm{~mm}$ 一 定にて, mAs 值(表示 $\mathrm{CTDI}_{\mathrm{W}}$ )を 200(37.55 mGy), 400 (75.11 mGy), 600(112.66 mGy), 800 mAs (150.21 mGy) と変化させた。 なお, 管電流は, $200 \mathrm{~mA}$ に固定し た。また，各 mAs 值において，30 画像を収集した。 次に, Microsoft 社製のプログラミングソフト (Visual C++6.0)を用いて，512×512 マトリクス内の画素值を 0 にし，その中に陽性像となる信号院影を 1 個配置さ せた画像を作成した。なお，信号陰影の直径は，後 述の1-2で利用した超急性期脳梗塞症例における虚 血領域の最小径が約 $10 \mathrm{~mm}$ であったこと, また, 事 


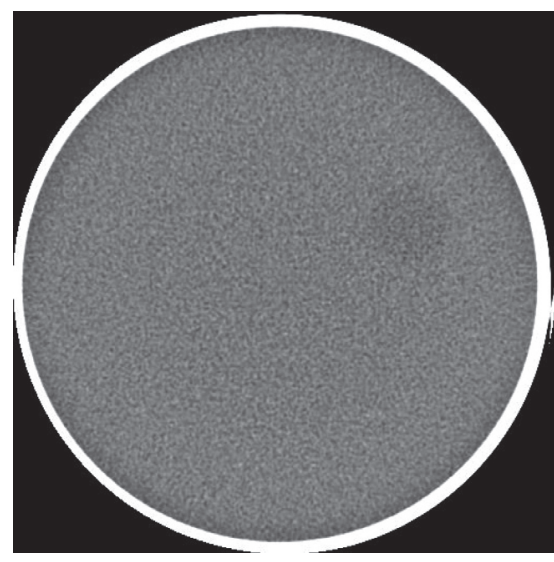

Fig. 1 Digital phantom images scanned with $200 \mathrm{mAs}$.

The diameter and intensity of signal in a image are $30 \mathrm{~mm}$ and 3 respectively.
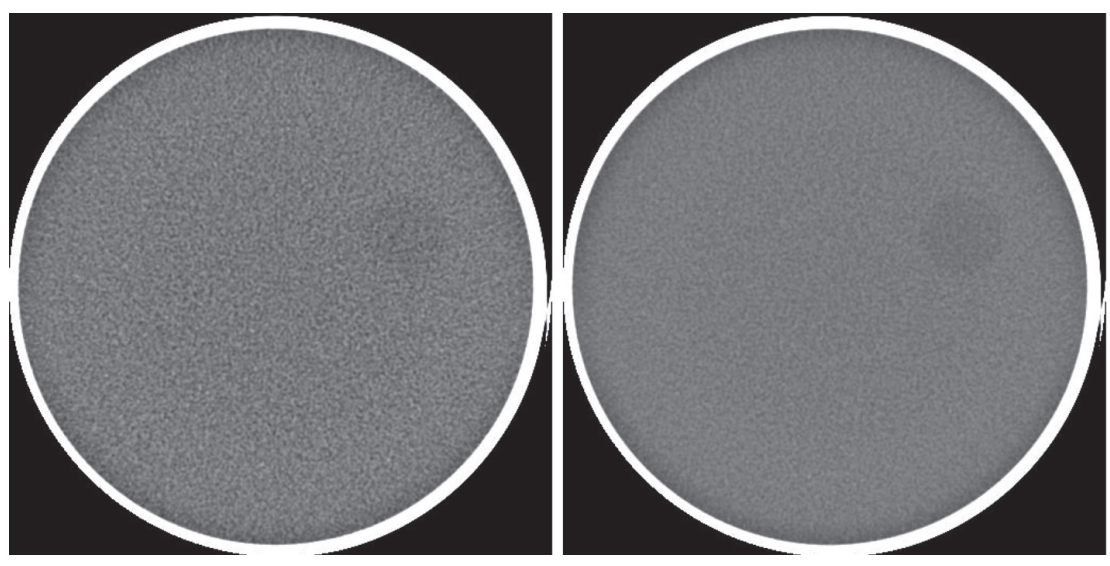

Fig. 2 Digital phantom images scanned with each current time product: (a) $200 \mathrm{mAs}$, (b) $800 \mathrm{mAs}$

a b

The diameter and intensity of signal in each image are $30 \mathrm{~mm}$ and 2 respectively.

前実験において信号径の異なるディジタルファントム 画像を用いた視覚的評価を実施した結果，信号径が $30 \mathrm{~mm}$ 以上では信号検出能が一定となったことか ら，10，15，20，25，30 mm と変化させ，信号コント ラストは， $1 ， 2 ， 3$ と変化させた。そして，計 15 種類 の信号が配置された画像を 2 セット, 計 30 画像を用 意した。なお，信号の位置は，乱数を用いて決定さ せた。最後に，撮影したノイズ画像と信号画像の減 算処理によりディジタルファントム 30 画像を作成し た. Fig. 1 に，200 mAs で撮影された信号コントラス トが 3 のディジタルファントム画像を, Fig. 2 に, 各 $\mathrm{mAs}$ 值で撮影された信号コントラストが 2 のディジ タルファントム画像を示す

\section{1-1-2 画像評価}

\section{1-1-2-1画像ノイズの測定}

$\mathrm{mAs}$ 值の異なる 4 条件の各ノイズ画像 30 画像か ら 5 画像を選択し, 画像の中央部抢よび周辺部 4 力 所に直径 $40 \mathrm{~mm}$ の円形 ROI を設定して ROI 内の画 素の標準偏差(standard deviation; SD)を求め, $\mathrm{mAs}$ 值ごとで加算平均した.

\section{1-1-2-2ROC 解析}

観察者実験は，まず，観察者に対し，あらかじめ 評価基準が一定となるようにトレーニングを行った。

各 $\mathrm{mAs}$ 值に扔けるディジタルファントム画像 30 画像 とノイズ画像 30 画像, 計 60 画像を高精細 21.3 型 liquid crystal display (LCD) モ ニ 夕(MS 35i2 3M monochrome：TOTOKU 社製)にランダムに表示し, WW 20，40，60，80 HU に設定した際の連続確信 度法を用いた観察者実験を暗室下で実施した。な お，観察者には，撮影条件に関する情報は提示して いない，また，表示する各条件の順番も観察者ごと にランダムにした，画像観察における時間的間隔は,
各条件間で 3 日以上空くよう設定した。視覚評価し た観察者は, 16 年抢よび 42 年の臨床経験をもつ 2 名の診療放射線技師と, 本施設に在籍する 5 名の学 部生の計 7 名である。学生が視覚評価を行った理由 は，事前に観察者実験を実施した結果，診療放射線 技師と学生間の評価結果に有意な差が認められず, 本観察者実験には読影能力の有無を必要しないと考 えたためである ${ }^{17)}$ 。最後に，得られた観察者 7 名の 確信度結果を ROC 解析ソフト ROCKIT(シカゴ大学 製)に入力し, 計 16 条件に扔ける各々の平均 ROC 曲 線と平均 ROC曲線下面積 (area under the curve; AUC) を求めた。なお, 観察者の研究参加に打いて, 臨床経験や評価結果などの個人情報を公開する旨を 説明したうえで，すべての観察者から承諾書を得て いる.

\section{1-2 臨床画像を用いた実験}

\section{1-2-1＼cjkstart画像データベース}

本実験に使用した画像データベースは，2006 年 4 月から 2007 年 9 月までに中央群馬脳神経外科病院で 16 DAS のマルチスライス CT 装置 (LightSpeed 16: GE 横河メディカルシステム社製)を用いて撮影され た，超急性期脳梗塞症例 30 例 (男性 16 名，女性 14 名) と, 正常症例 30 例 (男性 14 名, 女性 16 名)の計 60 例の CT 画像で構築されている. なお， 30 例の超 急性期脳梗塞症例に扮ける責任血管は，すべて中大 脳動脈 (middle cerebral artery; MCA) であり, MCA 領域全体に梗塞範囲が広がった症例が 8 例，MCA 領域の一部に限局した症例が 22 例(皮髄境界の消失 8 例，レンズ核・島皮質の不明瞭化 14 例) 存在する. CT 画像上に打ける早期虚血変化の有無の判定, およ び画像所見が超急性期脳梗塞であるのか否かの判定 

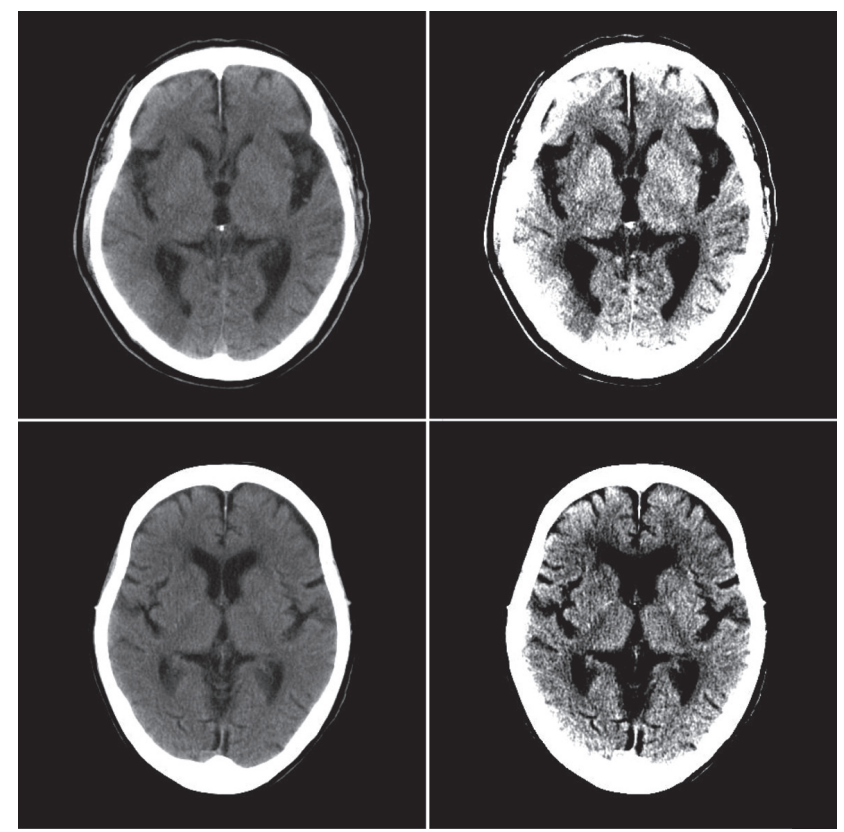

Fig. 3 Brain CT images with hyperacute ischemic stroke: (a), (c) window width $=80 \mathrm{HU}$; (b), (d) window width $=20 \mathrm{HU}$

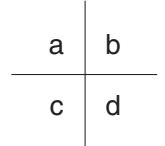

は, 2 名の脳神経外科医が magnotic resonance imaging (MRI) 拡散強調画像と見かけの拡散係数画像を確 認しながらコンセンサスのもとに決定された. 撮影 条件は, スキャンモード：コンベンショナル，管電 圧：120 kV, 管電流：200 mA, 回転時間 : $2.0 \mathrm{~s} / \mathrm{rot}$ (400 mAs), 再構成スライス厚: $5 \mathrm{~mm}(2.5 \mathrm{~mm} \times 8$ DAS), 再構成関数：STANDARD である。なお，本 研究に打ける画像データベースの利用に際し, 本施 設の倫理委員会の審査を受け, 承認を取得してい る. また, 本画像データベースは, 施設から CT 画像 が提供される前に患者情報データが削除され，個人 が特定できないよう匿名化されている。

\section{1-2-2 ROC 解析}

実験方法は, 超急性期脳梗塞症例 30 例と正常症 例 30 例, 計 60 例の CT 画像を上記と同一の高精細 LCD モニタにランダムに表示し，WWを 80 および $20 \mathrm{HU}$ と独立に設定して, 連続確信度法を用いた観 察者実験を暗室下で実施した。その後, 同一症例の CT 画像を同一モニ夕上に並べて配置し, 一方の画像 のWW を $80 \mathrm{HU}$ に, 他方の画像の WW $20 \mathrm{HU}$ に 設定して，両画像を利用した観察者実験を実施し た。な扮, 観察者実験の施行前には, 本研究内容, 観察方法，㧍よび評価基準について説明し，十分な トレーニングを実施した。 また, 観察者には, 画像観 察の際にWLを変化させて観察するよう依頼した。 特に, WW が $20 \mathrm{HU}$ に設定された画像は, 臨床にお いて見慣れていないため，WLを適宜変化させて観

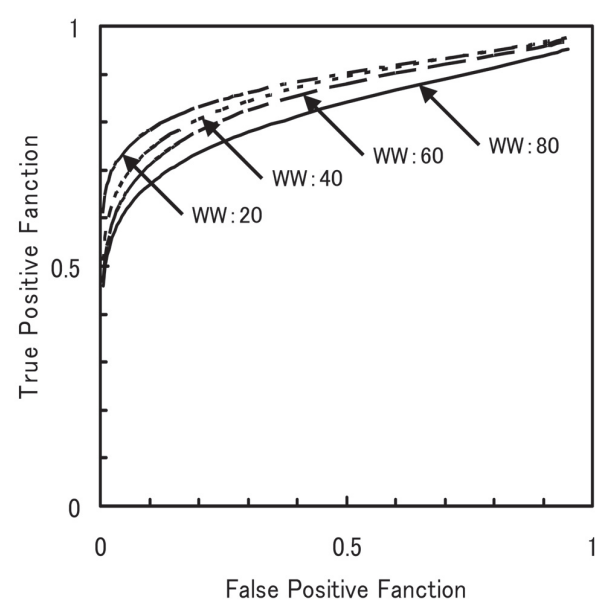

Fig. 4 Average ROC curves for each window width in phantom image scanned with $200 \mathrm{mAs}$.

察することや，陳旧性脳梗塞所見を無視して観察す ることなどを詳細に説明した，患者の臨床症状や既 往歴などの情報は提示していない，視覚評価した観 察者は, 3〜26 年(平均 13.4 18.9 )の臨床経験をもつ 10 名の診療放射線技師である。得られた確信度結果 から平均 ROC 曲線と平均 AUC を求めた。 なお, 1-1-2-2 と同様, 観察者の研究参加に打ける承諾書 は，すべての観察者から取得している. Fig. 3 に， WW 80 および $20 \mathrm{HU}$ に設定した際の超急性期脳 梗塞症例を示す.

\section{2. 結 果}

\section{2-1 ディジタルファントム画像を用いた実験}

本研究に抢いてノイズ画像から SD を求めた結 果, $\mathrm{mAs}$ 值の増加に伴って $\mathrm{SD}$ は低減した。なお, 200，400，600，800 mAsに扔けるSDは，それぞ れ， $\pm 3.4 ， \pm 2.4, \pm 2.0, \pm 1.7$ となった.

Fig. 4 拉よびFig. 5 に，それぞれ 200 および 800 mAs で撮影された画像に扔ける各 WW での平均 ROC 曲

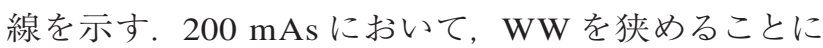
よって，信号検出能の向上が認められたが，800 mAs では, WW の変化による信号検出能の差が認められ ない結果となった。

Fig. 6 に, mAs 值と WW を変化させた 16 条件 に扔ける平均 AUCを示す。結果から, AUCは, $\mathrm{mAs}$ 值の増加, WW の狭小化によって上昇した. また，WWを $20 \mathrm{HU} に$ 設定することで，他のWW に比べて,AUCは極めて高值となった。 $800 \mathrm{mAs}$ に抢ける各 WW での平均 AUC 間の統計的有意差 検定 (両側ペアード $\mathrm{t}$ 検定)を行った結果，すべての WW 間において, 有意確率 $\mathrm{p}$ 值が 0.05 以上とな り，有意差は認められなかった。しかし，200， 


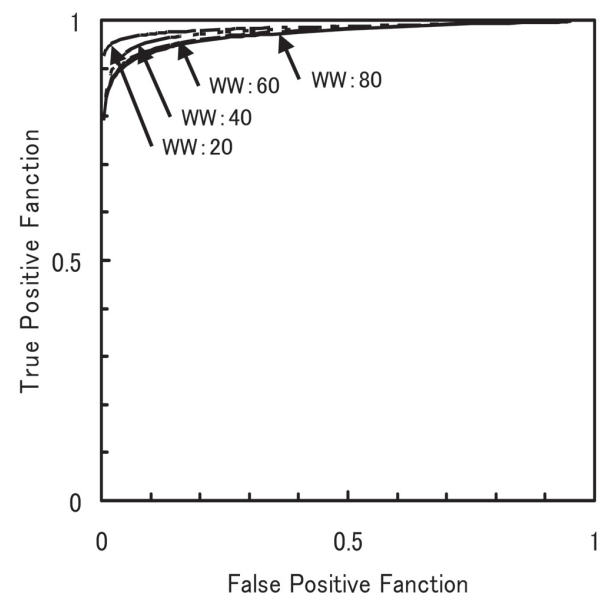

Fig. 5 Average ROC curves for each window width in phantom image scanned with 800 mAs.

400, 600 mAs において, 上記と同様, 各 WW での 平均 AUC 間の有意差検定を行った結果, WWを $20 \mathrm{HU}$ と $80 \mathrm{HU}$ に設定した際の平均 AUC 間では, 有意確率 $\mathrm{p}$ 值が 0.05 以下となり，有意差は認められ た $(\mathrm{p}=0.0144,0.0320,0.0172)$.

\section{2-2＼cjkstart臨床画像を用いた実験}

10 名の観察者の平均 ROC 曲線を Fig. 7 に示す. WWを $80 \mathrm{HU} に$ 設定した際の平均 AUCは $0.616 \pm 0.154$ となり，WW を $20 \mathrm{HU}$ に設定した際の平 均 AUC は $0.677 \pm 0.058$ となった。両 WW における平 均 AUC 間において, 統計的有意差検定(両側ペアー ド $\mathrm{t}$ 検定)を行った結果，有意確率 $\mathrm{p}$ 值が 0.05 以上と なり，有意差は認められなかった $(\mathrm{p}=0.3352)$. しか し，両 WWにおけるAUC間において，標準偏差の 差を検定した結果, 有意確率 $\mathrm{p}$ 值が 0.05 以下とな り，有意差は認められた $(\mathrm{p}=0.0251)$.

WW の異なる両画像を利用した際の平均 AUC は $0.720 \pm 0.127$ となった。 WWを $20 \mathrm{HU}$ に設定した際 の平均 AUCと, WW の異なる両画像を利用した際 の平均 AUC 間において, 有意差検定を行った結果, 有意確率 $\mathrm{p}$ 值が 0.05 以上となり, 有意差は認められ なかった $(\mathrm{p}=0.3124)$ 。しかし，WWを $80 \mathrm{HU}$ に設定 した際の平均 AUC との間においては，有意確率 $\mathrm{p}$ 值 が 0.05 以下となり，有意差は認められた $(\mathrm{p}=0.0206)$.

\section{3. 考 察}

超急性期脳梗塞の CT 画像所見である早期虚血変 化は，非常に淡い低吸収域を呈するため，読影に困 難を要するが, CT 検査の撮影条件や画像表示条件 を適切に設定することによって改善されると報告され ている2)。これまで，脳 CT 画像における低コントラス

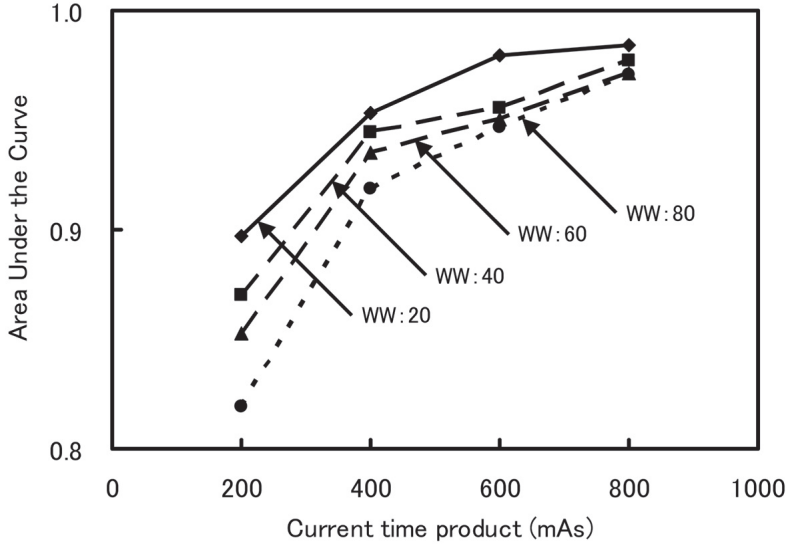

Fig. 6 Average area under the curves (AUC) in different current time products and window widths.

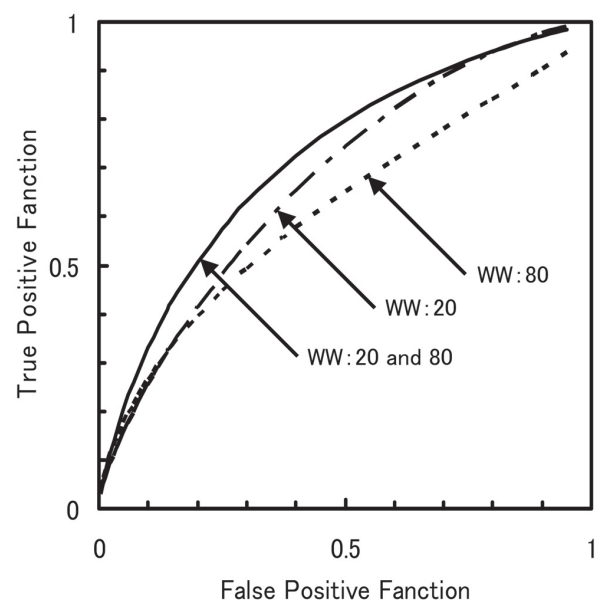

Fig. 7 Average ROC curves for 10 observers in clinical CT image.

卜検出能に関する撮影パラメータの検討は数多く実施 されている。しかし，画像表示条件の検討報告は極め て少なく，画像ノイズが異なる CT 画像における WW の調節が及ぼす低コントラスト検出能の影響について の検討はされていない。われわれは，基礎的実験とし て，超急性期脳梗塞の早期虚血変化をシミュレーショ ンしたディジタルファントム画像を作成し, 水ファン トム画像を併用して観察者実験を実施した。

本研究で用いたディジタルファントム画像は, 水 ファントム画像と低コントラストの信号を含んだ画像 との減算処理により作成されている，そのため，信号 の辺縁情報が，実際に撮影された CT 画像上の信号 と異なることが懸念される。市川らは, CT 画像の空 間周波数特性の影響を加味したデイジタルファントム 画像の作成方法を提案している18)。われわれは，作 成したディジタルファントム画像の信号コントラスト が 1〜3 と極めて小さく, 辺縁情報の差異が, 観察者 実験を実施した際の評価結果に影響を及ぼす程度で はないと考え, 単純な減算処理によりディジタルファ ントム画像を作成した。 
われわれは, ディジタルファントム画像と水ファン トム画像を用いて観察者実験を実施した。その結 果, 7 名の観察者における平均 AUC は, mAs 值の増 加と WW の狭小化によって上昇した。また，200， 400, $600 \mathrm{mAs}$ で撮影された画像に対し, WW 20 および $80 \mathrm{HU} に$ 設定した際の平均 AUC間におい て, 統計的有意差検定を行った結果, 有意差が認め られた。しかし，800 mAsで撮影された画像では，X 線量子ノイズの影響が低減されているため, WWを 変化させても信号検出能に差が生じなかった。

Fig. 4 における $200 \mathrm{mAs}$ で撮影された画像を用い た各 WW での平均 ROC 曲線の形状から, 信号が存 在するディジタルファントム画像における観察者の確 信度の変動が, ノイズ画像における確信度の変動に 比べて大きいことが推測される. 本研究で利用した ディジタルファントム画像 30 画像には, 信号コント ラストが 1 の直径が異なる㓌影が 10 画像含まれてお り, 観察する際にこれらの信号陰影が見落とされた ためと考える。しかし, $200 \mathrm{mAs}$ で撮影された画像 において，WWを狭くすることによって平均 AUCが 上昇していることから，WWの狭小化は，信号㓌影 の検出感度の向上が図れるものと考える。

近年, 画質と被ばく線量の最適化を図ることが可 能な CT 用自動露出機構を活用した撮影が実施され ている。この機能は, 画像ノイズの評価指標である $\mathrm{SD}$ を利用し, 出力線量を制御することで画質を標 準化するものである. 本研究において, 撮影された 水ファントム画像から SDを求めた結果, 上記の ROC 解析結果で有意差が認められた $600 \mathrm{mAs}$ $(112.66 \mathrm{mGy})$ では \pm 2.0 となった. よって, 各施設で 所有する直径 $200 \mathrm{~mm}$ の水ファントム画像上の SD が 土2.0を上回る場合には, 視覚的なノイズの影響を低 減させるために WW を広げるのではなく, WW を 20 HU に設定し, 画像コントラストを上昇させて観察す ることが，信号検出能の標準化につながるものと考え る。ただし，SDは，空間周波数特性に依存され，装 置ごとで信号検出能が異なるものと推測されることか ら, 施設ごとの検討が必要である. また，上記の検 討は, 均一な物質で構成されたディジタルファントム 画像を用いた実験結果に基づくものであり，実際の 臨床画像に直接反映させることはできない.しかし, 上記の結果から，WWを $20 \mathrm{HU}$ に設定することで, 低コントラスト検出能の向上が図れることは確証され ており, 左右対称性の特徵を利用して比較読影され る臨床画像においては, 強調された早期虚血変化が 容易に識別可能となるものと考える.

MELT Japan は, 超急性期脳梗塞の CT 画像を観 察する際, WW を 80 HU 以下に設定するよう推奨し
ている、また，筆者らは，各施設における頭部 CT 検 査のルーチン撮影条件を調査しており ${ }^{19)}$, その報告を 基に各施設の $\mathrm{mAs}$ 值を平均すると約 $350 \mathrm{mAs}$ であっ た。そこで，本研究で得られたFig. 6 の結果を利 用して, これらの各条件下で撮影および画像観察 された場合をシミュレーションすると, 平均 AUC が 0.893 となり，この平均 AUCを基準とした場 合，WWを $20 \mathrm{HU}$ に設定することで， mAs 值を約 $200 \mathrm{mAs}$ まで低減可能となる。このように，WWを 狭めて画像観察することは, 低コントラスト検出能の 向上のみならず, 出力線量の低減にも寄与する可能 性があるものと考える。

本研究では, 臨床画像を用いた観察者実験も実施 した。 上記のディジタルファントム画像と水ファント ム画像を用いた観察者実験において，WWを20 HU に設定することで，平均 AUC が極めて高值となった ため，われわれは，WWの設定を 80 および $20 \mathrm{HU}$ に決定し，10 名の観察者による評価を行った。その 結果, WW 80 および $20 \mathrm{HU}$ と個々に設定して観 察した際の平均 AUCは，それぞれ0.616 0.154 , $0.677 \pm 0.058$ となり, 両 WW の AUC 間における有意 差は認められなかった。しかし，標準偏差の差におい ては，有意差が認められた。これは，WWを $20 \mathrm{HU}$ に設定することで，観察者間の読影能力の変動を低 減できることを示した結果である。また，Fig. 7 にお ける WW $20 \mathrm{HU}$ に設定した際の平均 ROC 曲線の 形状から, 超急性期脳梗塞症例における観察者の確 信度の変動に比べ, 正常症例における観察者の確信 度の変動の方が大きいことが推測される。この結果 から，WWを $20 \mathrm{HU}$ に設定して観察することは，非 常に淡い早期虚血変化を検出できる一方, 無病誤診 率の増加を伴うことが示唆される，われわれは，同一 モニ夕上にWW の異なる画像を並べて配置し, 両画 像を利用した際の観察者実験を行った。 その結果,

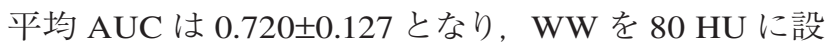
定した時と比べ，有意に増加した。近年の CT 装置 では，スキャン計画を立てる際に，再構成画像の表 示条件を複数設定することが可能である。したがっ て，WWを $80 \mathrm{HU}$ に設定した画像だけではなく, WW $20 \mathrm{HU}$ に設定した画像も併せて出力し, 両画 像を並べて観察することが, 早期虚血変化の更なる 読影精度の向上につながるものと考える. 今後の課題 として，放射線科医や脳神経外科医を対象とした観 察者実験を実施し，検討を重ねることが必要である.

\section{4. 結 語}

本研究では, 超急性期脳梗塞を対象としたディジ タルファントム画像を作成し, WW の変化が低コント 
ラスト検出能に与える影響について検討した。さら

に，超急性期脳梗塞症例が含まれる CT 画像を用い た観察者実験を実施して，WWの違いにおける読影 精度について検討した。 その結果，WWを狭めて画 像表示することは，画像ノイズが顕著な CT 画像にお いて低コントラスト検出能の向上につながり, さら に, 出力線量の低減に寄与する可能性があることが わかった。また，臨床画像において，WWを $20 \mathrm{HU}$ に設定することにより，読影精度の有意な向上は図れ なかったが, 観察者間の読影能力の変動を低減で
き,さらに，WWの異なる画像を並べて観察するこ とで，読影精度の向上が図れることがわかった。した がって, 超急性期脳梗塞の CT 画像診断において, WW を狭めた画像の利用は，非常に効果があるもの と考える.

\section{謝 辞}

本研究を実施するにあたり，多大なご協力をいた だきました，桐生厚生総合病院および中央群馬脳神 経外科病院の皆様に深く感謝いたします。

\section{参考文献}

1）成冨博章. 脳梗塞の early CT sign. 脳梗塞超急性期 Brain attack 時代の診断と治療. 医歯薬出版, 東京, 2001: 25-31.

2) 橋本洋一郎. 第 5 章 $\mathrm{X}$ 線 CT. 脳卒中を防ぐー病診連携 の最前線. 南山堂, 東京, 2001: 81-104.

3）前田正幸. 急性期脳梗塞の画像診断再入門 頭部 CT の 臨床的意義と課題一血栓溶解療法を行うにあたり一。画像 診断 2005; 25(12): 1454-1462.

4) von Kummer R, Allen KL, Holle R, et al. Acute stroke: usefulness of early CT findings before thrombolytic therapy. Radiology 1997; 205(2): 327-333.

5) 片田和廣. Neuro-imaging Update(画像診断の分野) 新し いCT 撮像法：脳血管障害への応用. 脳卒中 2004; 26(4): 552-556.

6）奥村美和. 低コントラスト分解能の評価方法. アールティ 2005; 27: 42-47.

7）小川正人. 急性期脳梗塞の単純 $\mathrm{CT}$ についてー低コントラ ス卜分解能一。日放技学誌 2006; 62(10): 1377-1379.

8）前田正幸. 急性期脳梗塞画像診断の標準化の現状 単純 CTの意義と標準化の現状. Innervision 2009; 24(1): 11-14.

9) 藤村一郎. 明日から使える頭部 CT 頭部単純 CT はノン ヘリカルかヘリカルか? ? ルールテイ 2009; 44: 25-33.

10）須永眞一, 長島宏幸, 小林 誠, 他. 16 列マルチスライ ス CT 装置における自作ディジタルファントムを用いた超 低コントラスト分解能の評価 急性期脳梗塞の CT 画像 所見の検出を目的とした撮影条件の適正化に関する基礎 的検討. 群馬県立県民健康科学大学紀要 2009; 4: 39-45.
11）浜口直子, 小寺秀一. 急性期脳梗塞診断に対するへリカ ルスキャンの適用に関する検討。日放技学誌 2010; 66(6): 632-640.

12）小川 彰。厚生労動科学研究費補助金「超急性期脳梗塞 に対する局所線溶解法の効果に関する臨床研究」. 平成 14 年度総括研究報告書, 2003.

13）平野照之. 脳卒中専門医のための脳血管障害の画像診断 急性期脳梗塞の頭部単純 $\mathrm{CT} \cdot$ 拡散強調画像. 分子脳血 管病 2008; 7(1): 78-85.

14) 細矢貴亮, 佐々木真理. 超急性期脳梗塞の CT. 救急で 役立つ頭部 CT · MRI．南江堂，東京，2010: 22-26.

15) Lev MH, Farkas J, Gemmete JJ, et al. Acute stroke: improved nonenhanced CT detection - benefits of softcopy interpretation by using variable window width and center level settings. Radiology 1999; 213(1): 150-155.

16）原秀剛, 井上年幸. 頭蓋内疾患評価用 $\mathrm{X}$ 線 CT ファン トムの試作 - 急性期脳梗塞模擬モデルの評価 - . Jpn J Med Phys 2006; 26 (Suppl 3): 183-184.

17）竹田 智, 後藤 淳, 丸野達也, 他. Receiver operating characteristics (ROC) 解析における信号の選択に関する検 討. 日放技学誌 2010; 66(11): 1467-1473.

18）市川勝弘, 原 孝則, 丹羽伸次, 他. CTに扔ける信号雑 音比による低コントラスト分解能の評価. 医用画像情報会 誌 2007; 24(3): 106-111.

19）長島宏幸，白石明久，小倉敏裕，他．群馬県内施設を対 象とした頭部 CT 検査における撮影線量と画質の比較評 価. 医学物理 2004; 24(4): 154-161.

||H||⿴囗十)

Fig. 1200 mAs で撮影された信号コントラストが3のディジタルファントム画像

なお，画像における信号の直径は $30 \mathrm{~mm}$ である.

Fig. 2 各 mAs 值で撮影された信号コントラストが 2 のディジタルファントム画像

(a) 抢よび(b)は，それぞれ $200 \mathrm{mAs}$ 拈よび $800 \mathrm{mAs}$ での画像である。 なお，各画像に扔ける信号の直径は $30 \mathrm{~mm}$ である.

Fig. 3 WW 80 および $20 \mathrm{HU}$ に設定した際の超急性期脳梗塞症例

(a) および (c)はWW が $80 \mathrm{HU}$ の画像，（b) および(d)はWW が $20 \mathrm{HU}$ の画像である.

Fig. $4200 \mathrm{mAs}$ で撮影された画像における各 WW での平均 ROC 曲線

Fig. $5800 \mathrm{mAs}$ で撮影された画像における各 WW での平均 ROC 曲線

Fig. 6 各 mAs 值および各 WW における平均 AUC

Fig. 7 臨床画像に扔ける観察者 10 名の平均 ROC 曲線 